\title{
Therapeutic effects of adipose derived mesenchymal stem cells on remyelination process in inflammatory demyelinating diseases
}

\author{
Nazem Ghasemi \\ Correspondence: Ghasemi_anatomy@yahoo.com

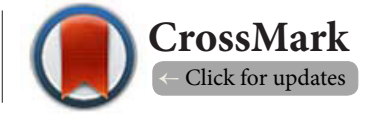

Department of Anatomical Sciences and Molecular Biology, School of Medicine, Isfahan University of Medical Sciences, Isfahan, Iran.

\begin{abstract}
Multiple sclerosis "MS" is a frequent demyelinating disease that affecting the central nervous system and associated with a progressive clinical course or severe disability in young adults. This narrative review summarizes the comprehensive information about adipose derived mesenchymal stem cells as one of the best sources for cell based therapy in demyelinating disease. The precise cause of MS is unknown, but the current evidence suggests that it can be linked to both genetic predisposition and environmental factors. During this abnormal condition, multifocal zones of inflammation due to focal immune cells infiltration and vascular abnormalities as well as change in plasmalemma permeability can occur which may are the primary cause of myelin sheath destruction. In addition to this pathological change, the formations of central nerve system plaques can also occur which crosstalk with the correct transmission of nerve impulse and finally lead to neuronal dysfunction. Conventional drug therapies for MS are not able to stop the degeneration of nerve tissue. So, stem cell based therapies has been proposed for the treatment of MS. In this narrative review, some of the characteristics and therapeutic effects of adipose-derived stem cells as a suitable cell source for cell transplantation in MS disease have been discussed.
\end{abstract}

Keywords: Central nervous system, multiple sclerosis, adipose-derived stem cell, cell transplantation

\section{Introduction}

The term "demyelinating diseases" refers to a multiple group of nervous system diseases in which the myelin sheath of neuron is damaged which leads to reduction or loss of neural function [1]. Although the exact cause of these abnormal conditions is yet obscure, but some of them can be caused by genetics and environmental factors such as infectious agents, autoimmune reactions, inflammatory processes, hypoxic-ischaemic condition, focal compression and by unknown other factors.

Inflammatory demyelinating diseases include multiple sclerosis (MS) together with Devic's disease (neuromyelitis optica) occur as a result of neurodegenerative processes in the central nervous system (CNS) [1]. Since Devic's disease is probably a variant of MS. Thus, in the following we will focus on MS disease.

MS or the commonest of the demyelinating diseases, has been considered as the most important autoimmune demyelinating disorder of the CNS which affects principally young adults and found in four clinical forms including: relapsing remitting MS (RRMS), primary progressive MS (PPMS), secondary progressive MS (SPMS), and progressive relapsing MS (PRMS) [2] (Table 1).

MS can lead to neurological dysfunction as well as physical or cognitive disability including vision problems, numbness, fatigue, tremor, dizziness, vertigo, hearing loss, speech and swallowing problems, bowel and bladder dysfunction [3].

The principal pathological characteristics of MS are focal infiltration of auto reactive $T$ cells and macrophages against myelin forming cells as well as components of myelin sheath, demyelination of axons, axonal loss, reduce myelin forming cells, vascular abnormalities, mitochondrial dysfunction, astrogliosis, and change in plasmalemma permeability and ion channels [4-6].

Howbeit the etiology of MS is yet unknown, but it appears to be linked to genetic predisposition including susceptible genes 
Table 1. The common subtype of multiple sclerosis and symptoms.

\begin{tabular}{|c|c|}
\hline Type of multiple sclerosis & MS course and symptoms \\
\hline $\begin{array}{l}\text { Relapsing remitting } \\
\text { multiple sclerosis (RRMS) }\end{array}$ & $\begin{array}{l}\text { RRMS is the most common } \\
\text { subtype of multiple sclerosis which } \\
\text { characterized by unpredictable acute } \\
\text { attacks of immune cells on myelin } \\
\text { and axons that followed by periods of } \\
\text { remission. RRMS is accompanied with } \\
\text { special symptoms including vision } \\
\text { impairments, numbness, spasticity, } \\
\text { fatigue, intestinal and urinary system } \\
\text { problems }\end{array}$ \\
\hline $\begin{array}{l}\text { Primary progressive } \\
\text { multiple sclerosis (PPMS) }\end{array}$ & $\begin{array}{l}\text { PPM largely affects the nerves of the } \\
\text { spinal cord and is accompanied with } \\
\text { special symptoms including stiff, } \\
\text { weakness, and problems with balance }\end{array}$ \\
\hline $\begin{array}{l}\text { Secondary progressive } \\
\text { multiple sclerosis (SPMS) }\end{array}$ & $\begin{array}{l}\text { SPMS is considered as a second phase } \\
\text { of the multiple sclerosis disease and is } \\
\text { associated with increase in weakness, } \\
\text { fatigue, stiff, Psychological impairment, } \\
\text { mental disorders, intestinal and urinary } \\
\text { system problems }\end{array}$ \\
\hline $\begin{array}{l}\text { Progressive relapsing } \\
\text { multiple sclerosis (PRMS) }\end{array}$ & $\begin{array}{l}\text { PRMS is the least common subtype of } \\
\text { MS which is associated with double } \\
\text { vision and eye pain, intestinal and } \\
\text { urinary system dysfunction, dizziness, } \\
\text { depression }\end{array}$ \\
\hline
\end{tabular}

in Human Leukocyte Antigen (HLA) region of Chromosome 6 such as HLA-DR2+ [7], HLA-DRB1 [8], DR15 [9], HLA-DQ6 [10], DQA 0102, combined with environmental influences such as exposure to viral and bacterial agents, vitamin $D$ deficiency [11], smoking [12] and exposure to UV radiation.

Glucocorticoids and immunomodulating agents such as interferon beta and glatiramer acetate are conventional therapies for MS. These agents through special mechanisms such as prohibition of immune cell activation, anti-inflammatory cytokines secretion, decrease in matrix metalloproteinase activity, and increase the expression of Foxp3 in T regulatory cells [13] can partially alleviate the progression of this pathologic condition. Thus, more effective therapies using stem cells have been proposed by researchers. In this review, we summarized the comprehensive information about the cell based therapy for demyelinating disease. In addition we focused on beneficial effects of in vivo stem cells transplantation and discussed some of the characteristics and therapeutic effects of adipose-derived stem cells as an ideal cell source for cell based therapy in MS disease.

\section{Review}

Materials and methods

In this paper, the results of recent research in the field of cell-based therapies in treatment of demyelinating diseases were compared and among all stem cells sources, adipose tissue-derived stem cell (ADSCs) properties as one of the best source was discussed.
Stem cells transplantation in demyelinating diseases

Stem cells are a population of undifferentiated biological cells that characterized by their self-renewal and ability to differentiate into other cell types. Mesenchymal stem cells (MSCs) which are a kind of non embryonic stem cells can be isolated from different tissues and widely used in the treatment of neurological disorders.

It has been shown that transplantation of human umbilical cord-derived MSCs (hUC-MSC) simultaneously with antiinflammatory treatment in MS patients, leads to reduced expanded disability status scale scores, relapse occurrence and decreased in inflammatory cytokines production due to the significant increase in Thelper (Th) 2 cells and decrease Th 1 cells. Therefore, with regard to improvement overall symptoms, these cells may be a suitable cell source for treatment of MS [14].

In a recent study human embryonic and human bonemarrow-derived MSCs (hBM-MSCs and hES-MSCs) were transplanted into experimental autoimmune encephalitis (EAE) which is a mouse model of MS. The results of this study showed that hES-MSCs are a better cell source for MS treatment as compared with BM-MSCs due to high EAE diseasemodifying effects and because of reduce clinical signs and neuronal demyelination [15]. Human wharton's jelly stem cellderived oligodendrocyte progenitor cells, can also promote the regeneration of myelin sheaths in mice brain lesions and diminished the clinical signs of MS [16]. In addition, wharton's jelly-derived stromal cells (WJ-MSC) implantation into EAE model of MS, have neuroprotective effects which were parallel with a reduction in autoantigen-induced $T$ cell proliferation that effectively modulated immune system responses. Thus, these effect suggesting that WJ-MSC may be a good cellular resource for cell transplantation to treat MS [17].

Available evidence indicates that pre-induced bone marrow MSC (with neurotrophin-3 and retinoic acid) transplantation combined with electro acupuncture treatment in demyelinated spinal cord (created by ethidium bromide) not only promoted MSC differentiation into oligodendrocyte-like cells, but also improved remyelination process which leads to sensorimotor functional recovery in the demyelinated spinal cord [18]. In addition, placental MSCs via reduced production of the anti-inflammatory proteins such as TNF-a- stimulated gene/ protein 6 (TSG-6) in inflammatory regions, have therapeutic effects in mice with EAE [19]. Other studies have shown the therapeutically benefit of BM-MSCs $[20,21]$, neural stem cell [22], oligoprogenitor (OP) like cells differentiated from spermatogonia [23], olfactory ensheathing cells [24] and embryonic stem cell-derived neural precursor cells [25] in animal models of demyelinating diseases.

In contrast with these studies, Nessler et al., showed that intravenously administration of human BM-MSCs has no effects on remyelination process and glial cell reactions in cuprizone model of MS because these cells were not able to cross the blood-brain barrier [26]. Thus, adipose-derived stem cell (ADSCs) as a suitable cell source has attracted attention 
of many researchers due to the unique characteristics. In this review some of these characteristics have been discussed according to available information. In addition, the probable mechanisms responsible for the therapeutic effects of these cells on remyelination process also have been discussed.

Adipose tissue is an attractive source of a pluripotent progenitor cells which called adipose-derived stem cells (AD$\mathrm{SCs})$. In the human body, there are different types of adipose tissue including white, brown, mammary, bone marrow and mechanical fat which are morphologically different and each type has distinct biological function. For example, the results of a previous study showed that the numbers and differentiation potential of ADSCs within white fat are higher than in brown fat [27]. Furthermore, Kalbermatten et al., in similar experiment reported that although ADSCs which isolated from both superficial and deep layer of human abdominal fat, express similar levels of the growth factors, but cell proliferation capacity of ADSCs that isolated from superficial layer is faster than those from other layers [28].

ADSCs are spindle-shaped cells with a fibroblast-like morphology which found in plentiful quantities (approximately 100 , 000 ADSCs per gram of fat tissue) [29] and can be isolated and cultured via a minimally invasive method according to our previous study [30] (Figure 1). These cells can be identified by the expression of MSCs markers including CD90, CD105, CD44 and pluripotent markers such as oct 4 and nanog. In addition, these cells do not express hematopoietic or endothelial markers such as CD34, CD45, and CD14 [31-33]. ADSCs have

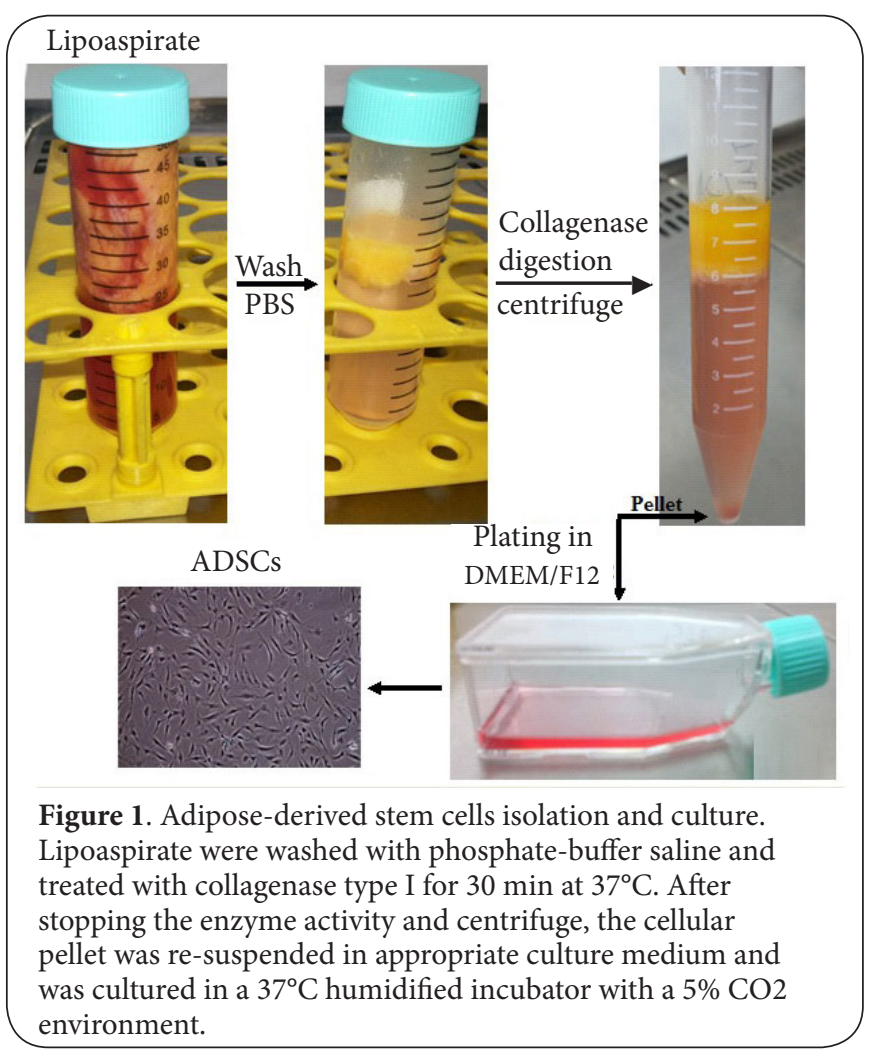

the ability to preserved their characteristics during repeated subculture and when cultured in the appropriate conditions are able to differentiated into other cells from different germ layers (Table 2) [31-36].

Table 2. Adipose-derived stem cells differentiation into other cells by special inductive factors.

\begin{tabular}{lll}
\hline Cell lineage & Inductive factors & References \\
\hline $\begin{array}{l}\text { Neurotrophic } \\
\text { factor secreting } \\
\text { cells }\end{array}$ & $\begin{array}{l}\text { Basic fibroblast growth factor, } \\
\text { Epidermal growth factor, Platelet- } \\
\text { derived growth factor, L-glutamine, } \\
\text { N2 supplement }\end{array}$ & {$[31,32]$} \\
\hline Neuron cells & $\begin{array}{l}\text { Basic fibroblast growth factor, } \\
\text { Epidermal growth factor }\end{array}$ & {$[31,33]$} \\
& $\begin{array}{l}\text { Epidermal growth factor, Hepatocyte } \\
\text { growth factor, Fibroblast growth }\end{array}$ & {$[34]$} \\
Hepatocyte & factor \\
\hline Chondrocyte & $\begin{array}{l}\text { Transforming growth factor- } \beta 3, \\
\text { cells }\end{array}$ & $\begin{array}{l}\text { Linoleic acid, Insulin-transferrin- } \\
\text { selenium, Ascorbate 2-phosphate }\end{array}$ \\
\hline Schwann cells & $\begin{array}{l}\text { Epidermal growth factor, Basic } \\
\text { fibroblast growth factor, Platelet- } \\
\text { derived growth factor, Forskolin }\end{array}$ & {$[31,36]$} \\
& &
\end{tabular}

\section{How do ADSCs work?}

Recently, successful cell transplantation and important experimental results proposed considerable therapeutic potential of ADSCs for cellular replacement in MS. The results of our previous study suggested that human ADSCs may be an ideal cell source for regenerative cure because can ameliorate the neuropathological signs and improve motor function in lysophosphatidylcholine model of MS. Our finding further confirms that these cells may promote remyelination process by either differentiation into mature oligodendrocyte or indirectly by promoting the survival of endogenous precursor cells via production of neurotrophic factors [30].

In similar experiment Tomita et al., [37] also reported that ADSCs trans-differentiation into a Schwann cells phenotype cells (dASC) and transplantation in a rat model of chronic denervation, enhanced nerve regeneration and motor functional recovery through promote remyelination process.

Another study's results demonstrated that intravenous and intra-peritoneal ADSCs administration into EAE model of MS can greatly reduce attack immune cells into the CNS and ameliorate severity of clinical scores due to their immunomodulative and neuroprotective effects [38].

It has been reported that intravenous transplantation of ADSCs can play a significant role in tissue repair processes through migration to the lesion areas and suppression of inflammatory responses in chronic progressive and relapsingremitting EAE models of MS [39].

In the other hand, Zhang et al., reported although infusion of wild type ADSCs (from EAE mice) has no therapeutic effects 
on the disease progression, but these cells are able to improve the disease course of autoimmune mediated demyelination by the regulation of the inflammatory responses [40].

In accordance to all published data, ADSCs play a significant role in tissue repair processes by virtue of their ability to neuroprotective and immunomodulative effects as well as their ability to migrate into the lesion areas and differentiation to mature oligodendrocyte which promoted remyelination process. Hence, in the following, we will focus on the special properties of ADSCs which are involved in promoting nerve regeneration and remyelination process including migration and differentiation potential, paracrine-mediated neuroprotection, immunomodulatory and anti-inflammatory effects.

\section{Mechanisms of potential utility of ADSCs}

Investigators have postulated that ADSCs migration and differentiation potential may be exclusive mechanisms which these cells used for repair and regenerate tissues.

Integrins or transmembrane receptors are one of the most important factors that are essential for cell migration. There are several subtypes of integrins which involved in a wide range of biological activities, such as immune patrolling and cell migration. Integrin a $4 \beta 1$ (or VLA-4) which expressed on leukocytes plasmalemma, by binding to its receptor on endothelium (VCAM-1), begins cell homing process. In addition, it has been demonstrated that this integrin also is expressed on ASCs, whereas not expressed in BM-MSC [41-43]. Thus, for MSC-based therapy in MS disease, ADSCs are a better cell source because they are able to cross the blood-brain barrier (BBB) and exert their action including neuroregenerative, immunomoulatory and anti-inflammatory effects.

Since, the inflammation of the CNS due to focal immune cells infiltration, is the primary cause of damage in MS patient, it is recommended that concomitant with ADSCs transplantation, anti-inflammatory drugs also used to reduced leukocytes homing.

Many of the identified growth factors such as neurotrophic, angiogenic and antiapoptotic factors can be secreted by ADSCs which play an important role in various cellular processes including cell proliferation, differentiation and maturation. Moreover, each of these growth factors exerts its biological activities through specific receptors [44-56] (Table 3).

As regards the short half-life of these growth factors as well as inability to cross the BBB when delivered peripherally, ADSCs transplantation instead of neurotrophic factors may be an ideal procedure for delivering these factors into demyelinating tissues.

These paracrine effects of ADSCs may be associated with modulation of immune responses via direct cell-to-cell interaction, increase the number of CD4+lymphocytes, reduce proinflammatory cytokine secretion and secrete prostaglandin E2, leukemia inhibitory factor and kynurenine $[\mathbf{5 7}, \mathbf{5 8}]$.

Concurrent with the migration of stem cells to inflammation area, in addition to the release of growth factors and anti inflammatory cytokines, these cells can also differentiate into oligodendrocyte cells. Moreover, ADSCs through paracrine effects are able to promote survival and proliferation of endogenous oligodendrocyte precursor cells which leading to further the process of remyelination. Another relevant finding of our previous study was that a high percentage of ADSCs which transplant in rat model of MS, expressed Olig2 and MBP that are special markers of oligodendrocyte [30]. Therefore, ADSCs may participate in remyelination process by differentiation into mature oligodendrocyte or by increasing

Table 3. The different nerve growth factors which secreted by adipose-derived stem cells.

\begin{tabular}{|c|c|c|c|}
\hline Type of growth factors & Related receptor & Dependent function & References \\
\hline Nerve growth factor (NGF) & TrkA, p75 NTR & $\begin{array}{l}\text { This factor can promote the biosynthesis of myelin } \\
\text { component sheaths in central and peripheral nerve system } \\
\text { and affect on oligodendrocyte differentiation }\end{array}$ & {$[44,45]$} \\
\hline $\begin{array}{l}\text { Brain derived neurotrophic factor } \\
\text { (BDNF) }\end{array}$ & TrkB, p75 NTR & $\begin{array}{l}\text { This factor can prevent neuronal degeneration and } \\
\text { improve neurological functional recovery after } \\
\text { transplantation }\end{array}$ & {$[46-48]$} \\
\hline $\begin{array}{l}\text { Glial cell line-derived } \\
\text { neurotrophic factor (GDNF) }\end{array}$ & GFRa1, RET & $\begin{array}{l}\text { This factor can prevent motor neuron degeneration and } \\
\text { is a highly potent trophic factor for spinal motor neurons } \\
\text { and central noradrenergic neurons }\end{array}$ & {$[49-51]$} \\
\hline $\begin{array}{l}\text { Vascular endothelial growth factor } \\
\text { (VEGF) }\end{array}$ & VEGF receptor- 2 & This factors has angiogenesis activity & \multirow{5}{*}[52,53]{} \\
\hline Basic fibroblast growth factor (bFGF) & FGFR1 to FGFR4 & This factors has angiogenesis activity & \\
\hline Hepatocyte growth factor (HGF) & C-Met receptor & This factors has angiogenesis activity & \\
\hline $\begin{array}{l}\text { Granulocyte macrophage-colony } \\
\text { stimulating factor (GM-CSF) }\end{array}$ & GM-CSF-receptor & This factors has angiogenesis activity & \\
\hline Transforming growth factor- $\beta$ (TGF- $\beta$ ) & TGFB receptor 1 & This factor has anti-apoptosis activity & \\
\hline Insulin-like growth factor-1 (IGF-1) & IGF1-R & This factor has anti-apoptosis and neuroprotection activity & {$[52-56]$} \\
\hline
\end{tabular}


the survival of endogenous precursor cells.

\section{Conclusion}

ADSCs are an ideal cell source for stem cell based therapies in treatment of demyelinating disease such as MS. These cells may take part in promote remyelination by either differentiating into mature myelin forming cells or by secreting various nerve growth factors which can promoting neural cell survival and proliferation. A large number of studies with ADSCs transplantation have already performed and the results of these studies demonstrated that these cells are effective in demyelinating disease treatment. With respect to the differentiation potential of ADSCs and the ability of these cells in secretion of many nerve growth factors as well as the ability to pass the BBB, suggests that intravenous injection or direct transplantation of ADSCs is a supreme procedure to deliver cellular and nerve growth factors into injured tissue for MS treatment.

\section{List of abbreviations}

ADSCs: Adipose-derived stem cells

MS: Multiple sclerosis

CNS: Central nervous system

RRMS: Relapsing remitting MS

PPMS: Primary progressive MS

SPMS: Secondary progressive MS

PRMS: Progressive relapsing MS

HLA: Human Leukocyte Antigen

MSCs: Mesenchymal stem cells

hUC-MSC: Human umbilical cord-derived MSCs

hES-MSCs: Human embryonic MSCs

hBM-MSCs: Human bone-marrow-derived MSCs

EAE: Experimental autoimmune encephalitis

WJ-MSC: Wharton's jelly-derived stromal cells

BBB: Blood-brain barrier

Competing interests

The author declares that he has no competing interests.

Acknowledgement

The author is grateful to Isfahan University of Medical

Sciences for their support.

Publication history

EIC: Giuseppe Musumeci, University of Catania, Italy.

Received: 18-Jan-2015 Revised: 05-Mar-2015

Accepted: 04-Apr-2015 Published: 13-Apr-2015

\section{References}

1. Kalman B and Lublin FD. Spectrum and classification of inflammatory demyelinating diseases of the central nervous system. Curr Neurol Neurosci Rep. 2001; 1:249-56. | Article | PubMed

2. Loma I and Heyman R. Multiple sclerosis: pathogenesis and treatment. Curr Neuropharmacol. 2011; 9:409-16. | Article | PubMed Abstract | PubMed Full Text

3. Gelfand JM. Multiple sclerosis: diagnosis, differential diagnosis, and clinical presentation. Handb Clin Neurol. 2014; 122:269-90. | Article | PubMed

4. Gandhi R, Laroni $A$ and Weiner HL. Role of the innate immune system in the pathogenesis of multiple sclerosis. J Neuroimmunol. 2010; 221:7-14. | Article | PubMed Abstract | PubMed Full Text
5. Kasper LH and Shoemaker J. Multiple sclerosis immunology: The healthy immune system vs the MS immune system. Neurology. 2010; 74 Suppl 1:S2-8. | Article | PubMed

6. Caprariello AV, Mangla S, Miller RH and Selkirk SM. Apoptosis of oligodendrocytes in the central nervous system results in rapid focal demyelination. Ann Neurol. 2012; 72:395-405. | Article | PubMed Abstract | PubMed Full Text

7. Stewart GJ, McLeod JG, Basten A and Bashir HV. HLA family studies and multiple sclerosis: A common gene, dominantly expressed. Hum Immunol. 1981; 3:13-29. | Article | PubMed

8. Amirzargar A, Mytilineos J, Yousefipour A, Farjadian S, Scherer S, Opelz G and Ghaderi A. HLA class II (DRB1, DQA1 and DQB1) associated genetic susceptibility in Iranian multiple sclerosis (MS) patients. Eur J Immunogenet. 1998; 25:297-301. | Article | PubMed

9. Masterman T, Ligers $\mathrm{A}$, Olsson $\mathrm{T}$, Andersson $\mathrm{M}$, Olerup $\mathrm{O}$ and Hillert J. HLA-DR15 is associated with lower age at onset in multiple sclerosis. Ann Neurol. 2000; 48:211-9. | Article | PubMed

10. Celius EG, Harbo HF, Egeland T, Vartdal F, Vandvik B and Spurkiand A. Sex and age at diagnosis are correlated with the HLA-DR2, DQ6 haplotype in multiple sclerosis. J Neurol Sci. 2000; 178:132-5. | Article | PubMed

11. Speer G. [Impact of vitamin $D$ in neurological diseases and neurorehabilitation: from dementia to multiple sclerosis. Part I: the role of vitamin $D$ in the prevention and treatment of multiple sclerosis] Ideggyogy Sz. 2013; 66:293-303. | Article | PubMed

12. O'Gorman C, Bukhari W, Todd A, Freeman S and Broadley SA. Smoking increases the risk of multiple sclerosis in Queensland, Australia. J Clin Neurosci. 2014; 21:1730-3. | Article | PubMed

13. Racke MK, Lovett-Racke AE and Karandikar NJ. The mechanism of action of glatiramer acetate treatment in multiple sclerosis. Neurology. 2010; 74 Suppl 1:S25-30. | Article | PubMed

14. Li JF, Zhang DJ, Geng T, Chen L, Huang H, Yin HL, Zhang YZ, Lou JY, Cao $B$ and Wang YL. The potential of human umbilical cord-derived mesenchymal stem cells as a novel cellular therapy for multiple sclerosis. Cell Transplant. 2014; 23 Suppl 1:S113-22. | Article | PubMed

15. Wang X, Kimbrel EA, ljichi K, Paul D, Lazorchak AS, Chu J, Kouris NA, Yavanian GJ, Lu SJ, Pachter JS, Crocker SJ, Lanza R and Xu RH. Human ESC-derived MSCs outperform bone marrow MSCs in the treatment of an EAE model of multiple sclerosis. Stem Cell Reports. 2014; 3:115-30. | Article | PubMed Abstract | PubMed Full Text

16. Mikaeili Agah E, Parivar K and Joghataei MT. Therapeutic effect of transplanted human Wharton's jelly stem cell-derived oligodendrocyte progenitor cells (hWJ-MSC-derived OPCs) in an animal model of multiple sclerosis. Mol Neurobiol. 2014; 49:625-32. | Article | PubMed

17. Donders R, Vanheusden M, Bogie JF, Ravanidis S, Thewissen K, Stinissen P, Gyselaers W, Hendriks JJ and Hellings N. Human Wharton?s jellyderived stem cells display immunomodulatory properties and transiently improve rat experimental autoimmune encephalomyelitis. Cell Transplant. 2014. | Article | PubMed

18. Liu Z, He B, Zhang RY, Zhang K, Ding Y, Ruan JW, Ling EA, Wu JL and Zeng YS. Electroacupuncture Promotes the Differentiation of Transplanted Bone Marrow Mesenchymal Stem Cells Pre-Induced with Neurotrophin-3 and Retinoic Acid into Oligodendrocyte-Like Cells in Demyelinated Spinal Cord of Rats. Cell Transplant. 2014. | Article | PubMed

19. Fisher-Shoval Y, Barhum Y, Sadan O, Yust-Katz S, Ben-Zur T, Lev N, Benkler C, Hod M, Melamed E and Offen D. Transplantation of placenta-derived mesenchymal stem cells in the EAE mouse model of MS. J Mol Neurosci. 2012; 48:176-84. | Article | PubMed

20. Jaramillo-Merchan J, Jones J, Ivorra JL, Pastor D, Viso-Leon MC, Armengol JA, Molto MD, Geijo-Barrientos E and Martinez S. Mesenchymal stromalcell transplants induce oligodendrocyte progenitor migration and remyelination in a chronic demyelination model. Cell Death Dis. 2013; 4:e779. | Article | PubMed Abstract | PubMed Full Text

21. Harris VK, Faroqui R, Vyshkina T and Sadiq SA. Characterization of autologous mesenchymal stem cell-derived neural progenitors as a feasible source of stem cells for central nervous system applications 
in multiple sclerosis. Stem Cells Transl Med. 2012; 1:536-47. | Article | PubMed Abstract | PubMed Full Text

22. Pluchino S, Quattrini A, Brambilla E, Gritti A, Salani G, Dina G, Galli R, Del Carro U, Amadio S, Bergami A, Furlan R, Comi G, Vescovi AL and Martino $G$. Injection of adult neurospheres induces recovery in a chronic model of multiple sclerosis. Nature. 2003; 422:688-94. | Article | PubMed

23. Nazm Bojnordi M, Movahedin M, Tiraihi T, Javan M and Ghasemi Hamidabadi $H$. Oligoprogenitor cells derived from spermatogonia stem cells improve remyelination in demyelination model. Mol Biotechnol. 2014; 56:387-93. | Article | PubMed

24. Sasaki M, Lankford KL, Radtke C, Honmou O and Kocsis JD. Remyelination after olfactory ensheathing cell transplantation into diverse demyelinating environments. Exp Neurol. 2011; 229:88-98. | Article | PubMed

25. Chen L, Coleman R, Leang R, Tran H, Kopf A, Walsh CM, Sears-Kraxberger I, Steward O, Macklin WB, Loring JF and Lane TE. Human neural precursor cells promote neurologic recovery in a viral model of multiple sclerosis. Stem Cell Reports. 2014; 2:825-37. | Article | PubMed Abstract I PubMed Full Text

26. Nessler J, Benardais K, Gudi V, Hoffmann A, Salinas Tejedor L, Janssen S, Prajeeth CK, Baumgartner W, Kavelaars A, Heijnen CJ, van Velthoven C, Hansmann F, Skripuletz T and Stangel M. Effects of murine and human bone marrow-derived mesenchymal stem cells on cuprizone induced demyelination. PLoS One. 2013; 8:e69795. | Article | PubMed Abstract | PubMed Full Text

27. Prunet-Marcassus B, Cousin B, Caton D, Andre M, Penicaud L and Casteilla L. From heterogeneity to plasticity in adipose tissues: sitespecific differences. Exp Cell Res. 2006; 312:727-36. | Article | PubMed

28. Kalbermatten DF, Schaakxs D, Kingham PJ and Wiberg M. Neurotrophic activity of human adipose stem cells isolated from deep and superficial layers of abdominal fat. Cell Tissue Res. 2011; 344:251-60. | Article | PubMed

29. Sen A, Lea-Currie YR, Sujkowska D, Franklin DM, Wilkison WO, Halvorsen YD and Gimble JM. Adipogenic potential of human adipose derived stromal cells from multiple donors is heterogeneous. J Cell Biochem. 2001; 81:312-9. | Article | PubMed

30. Ghasemi N, Razavi S, Mardani M, Esfandiari E, Salehi H and Zarkesh Esfahani SH. Transplantation of human adipose-derived stem cells enhances remyelination in lysolecithin-induced focal demyelination of rat spinal cord. Mol Biotechnol. 2014; 56:470-8. | Article | PubMed

31. Ghasemi N and Razavi S. Transdifferentiation potential of adiposederived stem cells into neural lineage and their application. Journal of Histology \& Histopathology. 2014; 1:12. | Article

32. Razavi S, Razavi MR, Zarkesh Esfahani H, Kazemi M and Mostafavi FS. Comparing brain-derived neurotrophic factor and ciliary neurotrophic factor secretion of induced neurotrophic factor secreting cells from human adipose and bone marrow-derived stem cells. Dev Growth Differ. 2013; 55:648-55. | Article | PubMed

33. Razavi S, Jahromi M, Amirpour $\mathrm{N}$ and Khosravizadeh Z. Effect of sertraline on proliferation and neurogenic differentiation of human adipose-derived stem cells. Adv Biomed Res. 2014; 3:97. | Article | PubMed Abstract | PubMed Full Text

34. Yin L, Zhu Y, Yang J, Ni Y, Zhou Z, Chen Y and Wen L. Adipose tissuederived mesenchymal stem cells differentiated into hepatocyte-like cells in vivo and in vitro. Mol Med Rep. 2015; 11:1722-32. | Article | PubMed Abstract | PubMed Full Text

35. Hashemibeni B, Goharian V, Esfandiari E, Sadeghi F, Fasihi F, Alipur R, Valiani A, Ghorbani M, Emami ZM, Shabani F and Goharian M. An animal model study for repair of tracheal defects with autologous stem cells and differentiated chondrocytes from adipose-derived stem cells. J Pediatr Surg. 2012; 47:1997-2003. | Article | PubMed

36. Razavi S, Ahmadi N, Kazemi M, Mardani M and Esfandiari E. Efficient transdifferentiation of human adipose-derived stem cells into Schwannlike cells: A promise for treatment of demyelinating diseases. Adv Biomed Res. 2012; 1:12. | Article | PubMed Abstract | PubMed Full Text

37. Tomita K, Madura T, Mantovani C and Terenghi G. Differentiated adiposederived stem cells promote myelination and enhance functional recovery in a rat model of chronic denervation. J Neurosci Res. 2012; 90:1392-402. | Article | PubMed

38. Yousefi F, Ebtekar M, Soleimani M, Soudi S and Hashemi SM. Comparison of in vivo immunomodulatory effects of intravenous and intraperitoneal administration of adipose-tissue mesenchymal stem cells in experimental autoimmune encephalomyelitis (EAE). Int Immunopharmacol. 2013; 17:608-16. | Article | PubMed

39. Payne NL, Sun G, McDonald C, Layton D, Moussa L, EmersonWebber A, Veron N, Siatskas C, Herszfeld D, Price J and Bernard CC. Distinct immunomodulatory and migratory mechanisms underpin the therapeutic potential of human mesenchymal stem cells in autoimmune demyelination. Cell Transplant. 2013; 22:1409-25. | Article I PubMed

40. Zhang X, Bowles AC, Semon JA, Scruggs BA, Zhang S, Strong AL, Gimble JM and Bunnell BA. Transplantation of autologous adipose stem cells lacks therapeutic efficacy in the experimental autoimmune encephalomyelitis model. PLoS One. 2014; 9:e85007. | Article | PubMed Abstract | PubMed Full Text

41. Rafei M, Campeau PM, Aguilar-Mahecha A, Buchanan M, Williams $P$, Birman E, Yuan S, Young YK, Boivin MN, Forner K, Basik M and Galipeau J. Mesenchymal stromal cells ameliorate experimental autoimmune encephalomyelitis by inhibiting CD4 Th17 T cells in a CC chemokine ligand 2-dependent manner. J Immunol. 2009; 182:5994-6002. | Article I PubMed

42. Gronthos S, Franklin DM, Leddy HA, Robey PG, Storms RW and Gimble JM. Surface protein characterization of human adipose tissue-derived stromal cells. J Cell Physiol. 2001; 189:54-63. | Article | PubMed

43. Constantin G, Majeed M, Giagulli C, Piccio L, Kim JY, Butcher EC and Laudanna $\mathrm{C}$. Chemokines trigger immediate beta2 integrin affinity and mobility changes: differential regulation and roles in lymphocyte arrest under flow. Immunity. 2000; 13:759-69. | Article | PubMed

44. Althaus HH, Kloppner S, Schmidt-Schultz T and Schwartz P. Nerve growth factor induces proliferation and enhances fiber regeneration in oligodendrocytes isolated from adult pig brain. Neurosci Lett. 1992; 135:219-23. | Article | PubMed

45. Urschel BA and Hulsebosch CE. Schwann cell-neuronal interactions in the rat involve nerve growth factor. J Comp Neurol. 1990; 296:114-22. | Article I PubMed

46. Zhang J, Li Y, Chen J, Cui Y, Lu M, Elias SB, Mitchell JB, Hammill L, Vanguri $\mathrm{P}$ and Chopp $\mathrm{M}$. Human bone marrow stromal cell treatment improves neurological functional recovery in EAE mice. Exp Neurol. 2005; 195:1626. | Article | PubMed

47. Zhang J, Li Y, Cui Y, Chen J, Lu M, Elias SB and Chopp M. Erythropoietin treatment improves neurological functional recovery in EAE mice. Brain Res. 2005; 1034:34-9. | Article | PubMed

48. Constantin G, Marconi S, Rossi B, Angiari S, Calderan L, Anghileri E, Gini B, Bach SD, Martinello M, Bifari F, Galie M, Turano E, Budui S, Sbarbati A, Krampera $\mathrm{M}$ and Bonetti $\mathrm{B}$. Adipose-derived mesenchymal stem cells ameliorate chronic experimental autoimmune encephalomyelitis. Stem Cells. 2009; 27:2624-35. | Article | PubMed

49. Gash DM, Zhang Z, Ai Y, Grondin R, Coffey R and Gerhardt GA. Trophic factor distribution predicts functional recovery in parkinsonian monkeys. Ann Neurol. 2005; 58:224-33. | Article | PubMed

50. Henderson CE, Phillips HS, Pollock RA, Davies AM, Lemeulle $C$, Armanini M, Simmons L, Moffet B, Vandlen RA, Simpson LCctSL, Koliatsos VE, Rosenthal $A$ and et al. GDNF: a potent survival factor for motoneurons present in peripheral nerve and muscle. Science. 1994; 266:1062-4. | Article | PubMed

51. Arenas $E$, Trupp M, Akerud $P$ and Ibanez CF. GDNF prevents degeneration and promotes the phenotype of brain noradrenergic neurons in vivo. Neuron. 1995; 15:1465-73. | Article | PubMed

52. Nakagami H, Maeda K, Morishita R, Iguchi S, Nishikawa T, Takami Y, Kikuchi Y, Saito Y, Tamai K, Ogihara T and Kaneda Y. Novel autologous cell therapy in ischemic limb disease through growth factor secretion by cultured adipose tissue-derived stromal cells. Arterioscler Thromb Vasc Biol. 2005; 25:2542-7. | Article I PubMed

53. Rehman J, Traktuev D, Li J, Merfeld-Clauss S, Temm-Grove CJ, Bovenkerk 
Nazem Ghasemi, Journal of Histology \& Histopathology 2015, http://www.hoajonline.com/journals/pdf/2055-091X-2-8.pdf

$\mathrm{JE}$, Pell CL, Johnstone BH, Considine RV and March KL. Secretion of angiogenic and antiapoptotic factors by human adipose stromal cells. Circulation. 2004; 109:1292-8. | Article | PubMed

54. Wabitsch M, Heinze E, Debatin KM and Blum WF. IGF-I- and IGFBP-3expression in cultured human preadipocytes and adipocytes. Horm Metab Res. 2000; 32:555-9. | Article | PubMed

55. Zhong J, Deng J, Huang S, Yang X and Lee WH. High K+ and IGF-1 protect cerebellar granule neurons via distinct signaling pathways. J Neurosci Res. 2004; 75:794-806. | Article | PubMed

56. Datta SR, Dudek H, Tao X, Masters S, Fu H, Gotoh Y and Greenberg ME. Akt phosphorylation of BAD couples survival signals to the cell-intrinsic death machinery. Cell. 1997; 91:231-41. | Article | PubMed

57. Salgado AJ, Reis RL, Sousa NJ and Gimble JM. Adipose tissue derived stem cells secretome: soluble factors and their roles in regenerative medicine. Curr Stem Cell Res Ther. 2010; 5:103-10. | Article | PubMed

58. Cawthorn WP, Scheller EL and MacDougald OA. Adipose tissue stem cells: the great WAT hope. Trends Endocrinol Metab. 2012; 23:270-7. | Article | PubMed Abstract | PubMed Full Text

\section{Citation:}

Ghasemi N. Therapeutic effects of adipose derived mesenchymal stem cells on remyelination process in inflammatory demyelinating diseases. J Histol Histopathol. 2015; 2:8.

http://dx.doi.org/10.7243/2055-091X-2-8 